\title{
Antibacterial, Antiulcerogenic and Antioxidant Activities of the Stem Bark Extracts of Entada africana
}

\author{
E. Tchamgoue Ngalani1,*, M. Boda ${ }^{1}$, S.H. Voundi Olugu' ${ }^{2}$, A.P. Amang ${ }^{3}$, S.P. Bouopda Tamo ${ }^{4}$, P.V. Tan ${ }^{5}$, F.X. Etoa ${ }^{1}$
}

${ }^{1}$ Department of Microbiology, Faculty of Science, University of Yaoundé 1, P.O. Box 812 Yaoundé, Cameroon.

${ }^{2}$ University Institute of Technology, University of Douala, P.O. Box 2701 Douala, Cameroon.

${ }^{3}$ Department of Biological Sciences, Faculty of Science, University of Maroua, P.O. Box 814 Maroua, Cameroon.

${ }^{4}$ Department of Biochemistry, Faculty of Science, University of Yaoundé 1, P.O. Box 812 Yaoundé, Cameroon.

${ }^{5}$ Department of Animal Biology and Physiology, Faculty of Science, University of Yaoundé 1, P.O. Box 812 Yaoundé, Cameroon.

\section{ART ICLE DETAIL S}

\section{Article history:}

Received 28 November 2019

Accepted 19 January 2020

Available online 19 April 2020

\section{Keywords:}

Gastrointestinal Disorders

Antibacterial Activity

Anti-Ulcerogenic Activity

Antioxidant Activity

Phenolic Compounds

Entada africana

\begin{abstract}
A B S T R A C T
In Cameroon, like elsewhere, medicinal plants are successfully used to treat gastro-intestinal diseases. Entada africana is a medicinal plant which different parts are used to treat stomach pain, diarrhea, dysentery and many other diseases. In order to show the efficiency of this plant in the treatment of gastrointestinal disorders, its antibacterial, antiulcerogenic and antioxidant activities were evaluated at Department of Microbiology (Laboratory of Microbiology) and Department of Animal Biology \& Physiology (Animal Physiology Laboratory); Faculty of Science, University of Yaoundé I, between Febuary 2015 and July 2016. Crude extract of E. africana was obtained using methylene chloride/methanol mixture and fractions by successive exhaustion in hexane, methylene chloride and ethyl acetate. Phytochemical analysis of secondary metabolites was done using colorimetric tests. The antibacterial study consisted to determine Inhibition Diameters (ID) by agar diffusion as well as the Minimum Inhibitory Concentration (MIC) and Minimum Bactericidal Concentration (MBC) using the tube macro dilution method against E. coli, S. typhi, P. aeruginosa, K. pneumonia, S. aureus and B. cereus. The anti-ulcerogenic and antioxidant properties of the methylene chloride/methanol crude extract was evaluated using indomethacin-induced ulcer in rats and levels of reduced glutathione (GSH) and malondialdehyde (MDA) in the stomach homogenate were measured. The phytochemical study revealed the presence of phenolics compounds. The Methylene chloride/methanol, hexane, methylene chloride and ethyl acetate extracts were active on the tested microorganisms with the following results respectively for ID and MIC: $8.50 \mathrm{~mm} \pm 0.50 \leq \mathrm{DI} \leq 18.00 \mathrm{~mm} \pm 1.00$ and $1.56 \mathrm{mg} / \mathrm{mL} \leq \mathrm{MIC} \leq 6.25$ $\mathrm{mg} / \mathrm{mL}$. The anti-ulcerogenic test showed that the methylene chloride/methanol extract exhibited a cytoprotective effect with ulcer indices varying from $1.98 \pm 0.24$ to $1.36 \pm 0.14$ when the rats were pretreated at 200 and $400 \mathrm{mg} / \mathrm{kg}$, respectively. Tissue levels of MDA reduced (23.04\%) while those of GSH increased (14.29\%) following treatment with extract. The antibacterial, anti-ulcerogenic and antioxidant activities exerted by these plant extracts could be due to the presence of phenolic compounds. These properties would make this plant an "all-in-one" medicine, which justify its use in treatment of gastrointestinal disorders.
\end{abstract}

\section{Introduction}

The digestive tract is a vast interface between the host and its environment. It plays a vital role in the process of food digestion from birth and throughout life, although encounters a lot of challenges. Among these conditions, gastrointestinal infections are the most common underlying diarrhea as one of the main causes of morbidity and mortality in developing countries, causing the death of 160 to 200 children under five years of age every day [1]. Diarrhea affects all age groups and is responsible for 2.4 million deaths each year worldwide [2]. Infections of the gastrointestinal tract can come from a multitude of different germs (viruses, bacteria and parasites) and those of bacterial origin are less important but more severe than those of viral origin [3]. The main bacterial germs responsible for gastrointestinal infections are: Salmonella, Shigella, Escherichia coli, Staphylococcus aureus, Clostridium difficile, Vibrio cholerae, Bacillus cereus, Campylobacter [4]. Their physiopathological mechanisms are summarized in the production of enterotoxins or the invasion of the intestinal mucosa leading respectively to cholera syndrome or dysenteric syndrome. On one hand, the preformed toxin present in a food or synthesized by the bacterium in the digestive tract of the patient modifies the work of the enterocytes ion pumps. This results in increased 
situation is much more alarming in less affluent countries. This is the case of Cameroon, where ulcerative stomach disease has a prevalence of $10.40 \%$ [10]. In addition to hygieno-dietary treatment based on rest and a balanced diet, modern medicine provides people with gastrointestinal disorders with several drugs such as antacids, anti-secretory drugs, transit slowdowns, adsorbents and antibiotics. As the cost of modern medicine continues to rise, these pharmaceutical products are inaccessible to the most affected social strata in countries weakened by poverty and underdevelopment. In addition, there is the scarcity of hospitals in rural areas and the reluctance of patients due to the multiple side effects associated with taking several drugs daily. In response to these problems, about $80 \%$ of the population in developing countries uses traditional herbal medicines for primary health care [11] where applicable, the use of Entada africana in the treatment of gastrointestinal disorders.

Entada africana is a shrub of the Mimosaceae family with a height of about 7 meters tall. The barks of this plant, sometimes light or yellowish grey, are deeply cracked, corky with transverse bands. Its branches have small green leaves arranged between 8 and 24 pairs. The flowers, small, isolated, fragrant, creamy-white or greenish-yellow in color, are grouped into axillary ears 7 to $10 \mathrm{~cm}$ long and $13 \mathrm{~mm}$ in diameter, fasciculated by 3-5 in the axils of fallen leaves or young leaves. Savannah specie, it is widespread from Senegal to Cameroon, but also occurs in Democratic Congo and Uganda.

E. africana is characterized by its multiple uses in traditional medicine. Its bark is used as antidiarrheal and is involved in the preparation of remedies for the treatment of oral and throat disorders [12]. The decoctions of barks are used against dysentery and as an antiseptic. The leaves are used to prevent wound suppurations [13] and in infusion are indicated to treat stomach aches. This plant is also used to treat fever, skin and respiratory infections, diarrhea, diabetes, hypertension, liver and stomach disorders [14-16].

The use of plant preparations dates back to antiquity and is undoubtedly effective. Such is the case of the decoctions and infusions of Entada africana that relief people suffering from gastrointestinal disorders. However, experts in the field do not seem to distinguish between infectious or non-infectious affections, and for this purpose, they use an "all-in-one" approach. The World Health Organization now recommends that the quality and effectiveness of plants used in traditional medicine be evaluated using modern techniques in order to enhance their value. In order to provide a scientific basis for the use of E. africana in the traditional treatment of gastrointestinal disorders, the objective of this work is to evaluate the antibacterial, anti-ulcerogenic and antioxidant activities of the bark of this plant.

\section{Experimental Methods}

\subsection{Plant Material and Preparation of Extracts}

Fresh stem barks of E. africana were harvested in Dschang in the West region of Cameroon in May 2013 and botanical identification of plant was done at the National Herbarium of Cameroon by comparing with existing herbarium voucher specimen No. 8605/SRF/CAM. The above plant parts were dried at room temperature, crushed and one hundred grams (100 g) of dry powder was macerated for 48 hours in $500 \mathrm{~mL}$ of the methylene chloride/methanol mixture $(1: 1, \mathrm{v} / \mathrm{v})$ before being filtered on Whatman paper No. 1. The filtrate was concentrated in rotary evaporator (Heidolph VV 2000) [17]. For hexane, methylene chloride and ethyl acetate extracts, $8 \mathrm{~g}$ of methylene chloride/methanol extract was fractionated by successive exhaustion in $50 \mathrm{~mL}$ of hexane, then methylene chloride and finally ethyl acetate. After filtration, the various filtrates were concentrated in the rotary evaporator. The extraction yield was calculated according to the following formula:

Extraction yield $(\%)=($ Mass of the extract obtained $(\mathrm{g}) /$ Initial powder mass (g)) x 100

The methylene chloride/methanol, hexane, methylene chloride and ethyl acetate extracts were prepared at a concentration of $100 \mathrm{mg} / \mathrm{mL}$ in DMSO $10 \%$. Gentamicin (1 mg/mL) was used as the reference antibiotic.

\subsection{Bacterial Species}

Six bacterial species responsible for gastrointestinal diseases were used. These were Escherichia coli, Salmonella typhi, Pseudomonas aeruginosa, Klebsiella pneumoniae, Staphylococcus aureus and Bacillus cereus; provided by the Laboratory of Medical Bacteriology of the Centre Pasteur du Cameroun (CPC). These bacteria were maintained on agar slant at $4{ }^{\circ} \mathrm{C}$ and were sub cultured on the fresh appropriate agar plate $24 \mathrm{~h}$ prior to any antimicrobial test.

\subsection{Culture Media}

Mueller Hinton Agar (MHA; Fortress) was used for the diffusion assays and minimal bactericidal concentration determination while Mueller Hinton Broth (MHB; Fortress) was used to determine minimal inhibition concentration. They were prepared according to the manufacturer's instructions.

\subsection{Animals}

Male Wistar rats (175 - $200 \mathrm{~g}$ ) were used for anti-ulcerogenic tests. The animals were raised on a standard laboratory diet and tap water in the animal house of the Faculty of Science, University of Yaoundé 1. Prior authorization for the use of laboratory animals in this study was obtained from the Cameroon National Ethics Committee (Reg. No. FWAIRB00001954).

\subsection{Phytochemical Screening}

Phytochemical screening was carried out on methylene chloride/methanol extract to look for the presence of large chemical families of compounds with antimicrobial, antiulcer and antioxidant properties such as phenols, polyphenols, flavonoids, tannins, alkaloids, saponins and anthocyanins; using the standard procedure described in the literature by Odebeyi and Sofowora [18] and Harbone [19].

\subsection{Evaluation of the Antibacterial Activity \\ 2.6.1 Determination of the Inhibition Diameters (ID)}

The diameters of the inhibition zones were determined by the diffusion method using the well technique as described by Adesokan et al. [20] with slight modifications. The bacterial inoculum of about $1.5 \times 10^{6} \mathrm{CFU} \mathrm{mL}^{-1}$ obtained from McFarland turbidity standard No. 0.5. The suspension was standardized by adjusting the optical density to 0.1 at $560 \mathrm{~nm}$ (JENWAY 6305 Spectrophotometer). The MHA medium poured into the petri dishes was inoculated by spreading $100 \mu \mathrm{L}$ of a bacterial inoculum on its surface. Wells with a diameter of $6 \mathrm{~mm}$ were drilled on this medium using the bold end of a pipette tip and $60 \mu \mathrm{L}$ of each test solution were dropped into the wells. After a 45-minute pre-diffusion at room temperature, the petri dishes were incubated at $37^{\circ} \mathrm{C}$ for $24 \mathrm{~h}$. The ID was then measured around the well and extract with ID $>7 \mathrm{~mm}$ was considered. Each test was done in triplicate and the values were expressed as an average \pm MSE (Mean Standard Error).

\subsubsection{Determination of Minimum Inhibitory and Bactericidal Concentrations (MIC) and (MBC)}

The MIC of test samples found active by the diffusion test were determined by liquid macro dilution method like described by Clinical and Laboratory Standards Institute (CLSI) [21] with slight modifications. Mueller Hinton Broth containing extract prepared at the concentration of $50 \mathrm{mg} \mathrm{mL}^{-1}$ was serially diluted two-fold to obtain concentrations range of 0.39 to $50 \mathrm{mg} \mathrm{mL}^{-1}$ in total volume of $2 \mathrm{~mL}$. Mueller Hinton Broth containing gentamycin $\left(160 \mu \mathrm{g} \mathrm{mL}^{-1}\right)$ was also diluted the same way to obtain concentrations range to 1.25 to $160 \mu \mathrm{gL}^{-1}$. Each tube as well as the negative control (extract-free) was inoculated with $50 \mu \mathrm{L}$ of standard inoculum of bacterial tests and incubated at $37{ }^{\circ} \mathrm{C}$ for $24 \mathrm{~h}$. Microbial growth was determined by observing the turbidity in the tube. The lowest concentration showing no visible growth of the germ was considered as the MIC. The MBC was determined by subculturing the contents of tubes with concentrations greater than or equal to the MIC on Mueller Hinton agar. The MBC was considered to be the lowest concentration of extract that left no more than $0.01 \%$ of survivors of the initial inoculum remaining. The substance was considered as bactericidal when MBC/MIC $<4$ or bacteriostatic when MBC/MIC $\geq 4$ [22]

\subsection{Evaluation of the Anti-Ulcerogenic Activity of the Methylene} Chloride/Methanol Extract

The anti-ulcerogenic activity of the methylene chloride/methanol extract of E. africana was determined using the experimental protocol described by Santhakumari and Pillai [23] with some modifications. Five groups of 5 rats deprived of food for 48 hours prior to experimentation but having free access to tap water were used. Groups 1 and 2 served as negative control and received distilled water and DMSO $10 \%$ respectively. Group 3 was used as positive control and was treated with sucralfate 60 $\mathrm{mg} / \mathrm{kg}$ ). The 2 last groups received the plant extract at the doses 200 and $400 \mathrm{mg} / \mathrm{kg}$ by oral route. 1 hour before they were given indomethacin (50 $\mathrm{mg} / \mathrm{kg}$ ) by gavage. Five hours later, the animals were sacrificed and the abdomens opened. Isolated by section from the pylorus and esophagus, each stomach received $10 \mathrm{~mL}$ of formaldehyde solution (2\%) by injection. Ten minutes later, these stomachs were opened along the large curve. 
Then the lengths and widths of the lesions of each animal were measured and scored as earlier described by Martin et al. [24]. For non-ulcer surfaces; vessel dilations and small ulcer points; ulcers less than or equal to $4 \mathrm{~mm}$ long and ulcers greater than or equal to $5 \mathrm{~mm}$ long, recorded respective scores as $0.00 ; 1.00 ; 2.50$ and 5.00 . Finally, the ulceration surface, the percentage of ulcerated surface (\%US), the ulcer index (IU) and the percentage of inhibition (\%I) were calculated.

The ulceration surface of a group is equal to the average of the products of the lengths and widths of the different lesions in the batch \pm Mean Standard Error (MSE).

The percentage of the ulcerated surface (\%US) of a rat's stomach was calculated according to the following formula: \%US = (Average ulcerated surface $\left.\left(\mathrm{mm}^{2}\right) / 675 \mathrm{~mm}^{2}\right) \times 100.675 \mathrm{~mm}^{2}$ representing the average glandular surface of the stomach [25]. The ulcer index (UI) is the average ulcer score of each treatment \pm MSE.

The percentage of ulcer inhibition of a given treatment is determined based on the negative control group according to the formula below,

\section{$\%$ I = ((UI of negative control batch - UI of Experimental batch) /}

(UI of the negative control batch)) x100

\subsection{Measurement of Mucus Production}

The mucus covering of each stomach was gently scraped using a glass slide and the mucus weighed carefully using a sensitive digital electronic balance.

\subsection{Evaluation of the Anti-Antioxidant Activity of the Methylene Chloride/Methanol Extract}

\subsubsection{Preparation of Stomach Homogenates}

In an ice tray, $1 \mathrm{~g}$ of stomach from each animal was crushed and homogenized with $5 \mathrm{~mL}$ Tris- $\mathrm{HCl}$ buffer $(50 \mathrm{mM})$. After centrifugation at $5700 \mathrm{rpm}$ for $30 \mathrm{~min}$, the homogenate was recovered and stored in a freezer for the determination of reduced glutathione and malondialdehyde.

\subsubsection{Dosage of Reduced Glutathione (GSH)}

The reduced glutathione contained in the stomach was measured by the method written by Ellman [26]. In a test tube, $0.02 \mathrm{~mL}$ of stomach homogenate was mixed with $3 \mathrm{~mL}$ of Ellman reagent. After homogenizing, colouring was allowed to develop for 60 minutes at room temperature. The absorbance of each tube was then read at $412 \mathrm{~nm}$. The calculation of the GSH rate was done using Beer-Lambert's law:

\section{DO $=$ E.l.C.}

$\mathrm{GSH}$ concentration $=\mathrm{DO} \mathrm{V}_{\mathrm{t}} /$ c.L.Vi.morg

\subsubsection{Dosage of Malondialdehyde (MDA)}

The method described by Wilbur et al. [27] was used to determine the amount of malondialdehyde contained in the stomach. Two milliliters (2 $\mathrm{mL}$ ) of stomach homogenate were mixed with $1 \mathrm{~mL}$ of $20 \%$ trichloroacetic acid and $2 \mathrm{~mL}$ of $0.67 \%$ thiobarbituric acid. The tubes were incubated in a water bath at $90{ }^{\circ} \mathrm{C}$ for $10 \mathrm{~min}$. They were then cooled in tap water and centrifuged at $5700 \mathrm{rpm}$ for 10 minutes. The supernatant was sampled and the absorbance was read at $532 \mathrm{~nm}$. The malondialdehyde concentration was calculated using the molar extinction coefficient $(\varepsilon)$.

\section{MDA concentration $=\mathrm{DO} \mathrm{V}_{\mathrm{t}} / \varepsilon \cdot \mathrm{L} \cdot \mathrm{Vi} \cdot \mathrm{m}_{\mathrm{org}}$}

DO: optical density measured at $530 \mathrm{~nm}$; $\varepsilon$ : molar extinction coefficient $=1.56 \times 10^{5} \mathrm{~cm}^{-1} \mathrm{mmol}^{-1} ; \mathrm{l}$ : length of the tank $(1 \mathrm{~cm}) ; \mathrm{V}_{\mathrm{t}}$ : total volume of the homogenate; $\mathrm{m}_{\text {org: }}$ mass of organ used to prepare the homogenate; $\mathrm{V}_{\mathrm{i}}$ : volume used for dosing; GSH concentration in tissue (mmol/g) ; MDA concentration in the tissue $(\mathrm{nmol} / \mathrm{g})$

\subsubsection{Statistical Analysis}

The results were expressed as an arithmetic mean \pm Mean Standard Error. These results were analyzed using GraphPad InStat (D) software at $5 \%$ probability ( $\mathrm{p}<0.05$ ) by variance analysis (One Way ANOVA), followed by the Tukey test for mean comparisons.

\section{Results and Discussion}

\subsection{Extraction Yields}

Methylene chloride/methanol, hexane, methylene chloride and ethyl acetate used to obtain different extracts. The maceration of $100 \mathrm{~g}$ of dry powder of E. africana stem barks permitted to obtain $10 \mathrm{~g}$ of methylene https://doi.org/10.30799/jnpr.084.20060101 chloride/methanol extract, for an extractive yield of $10.00 \%$. The successive exhaustion of $8 \mathrm{~g}$ of methylene chloride/methanol extract in hexane, methylene chloride and ethyl acetate given $2.52 \mathrm{~g}$ of hexane extract, $3.25 \mathrm{~g}$ of methylene chloride extract, and $1.60 \mathrm{~g}$ of ethyl acetate extract for the extractive yields of 31.50, 40.63 and 20.02 respectively (Table 1).

Table 1 Extraction yields

\begin{tabular}{ll}
\hline Extracts & Yields (\%) \\
\hline MET. CHL/METH & 10.00 \\
HEX. & 31.50 \\
MET. CHL & 40.63 \\
EA & 20.02 \\
RES & 7.85 \\
\hline
\end{tabular}

[MET. CHL/METH : methylene chloride/methanol extract ; HEX : hexane extract $M E T . C H L$ : methylene chloride extract; EA : ethyl acetate extract; RES : residual extract of E. africana]

\subsection{Phytochemical Composition}

Medicinal plants contain a number of secondary metabolites which serves as biological activity in them. To detect the presence of large chemical families of compounds with antimicrobial, antiulcer and antioxidant properties, some phytochemical tests have been performed. The results show that the methylene chloride/methanol extract of $E$. africana contains flavonoids, phenols, saponins, anthocyanins and tannins (Table 2). However, it is free from alkaloids. These results corroborate with the findings obtained by Tibiri et al. [15] and Njayou et al. [28] respectively on aqueous extract and methylene chloride/methanol extract of stem bark of E. africana.

Table 2 Phytochemical composition of methylene chloride/methanol extract of $E$ africana

\begin{tabular}{ll}
\hline Secondary metabolites & methylene chloride/methanol extract of \\
& Entada africana \\
\hline Alcaloïdes & - \\
Anthocyanins & + \\
Flavonoids & + \\
Phenols & + \\
Saponins & + \\
Tannins & + \\
\hline -:absence +: presence &
\end{tabular}

Table 3 Inhibition diameters (in $\mathrm{mm}$ ) of the extracts of Entada africana

\begin{tabular}{|c|c|c|c|c|c|c|}
\hline & $\begin{array}{l}\text { MET. } \\
\text { CHL/METH. }\end{array}$ & E.A. & MET. CHL. & HEX. & RES. & GENT. \\
\hline B.C. & $10.50 \pm 0.50$ & $\begin{array}{l}15.00 \pm \\
1.00^{\mathrm{a}}\end{array}$ & $\begin{array}{l}10.50 \pm \\
0.50\end{array}$ & $\begin{array}{l}12.50 \pm \\
0.50\end{array}$ & $\begin{array}{l}0.00 \pm \\
0.00\end{array}$ & $\begin{array}{l}24.00 \pm \\
1.00^{\mathrm{b}}\end{array}$ \\
\hline STA. & $10.00 \pm 0.00$ & $\begin{array}{l}15.00 \pm \\
0.00^{\mathrm{a}}\end{array}$ & $\begin{array}{l}11.00 \pm \\
0.00\end{array}$ & $\begin{array}{l}11.00 \pm \\
1.00\end{array}$ & $\begin{array}{l}0.00 \pm \\
0.00\end{array}$ & $\begin{array}{l}24.50 \pm \\
0.50^{\mathrm{b}}\end{array}$ \\
\hline E.C. & $10.50 \pm 0.50$ & $\begin{array}{l}16.50 \pm \\
0.50^{\mathrm{a}}\end{array}$ & $\begin{array}{l}11.50 \pm \\
0.50\end{array}$ & $\begin{array}{l}11.00 \pm \\
0.00\end{array}$ & $\begin{array}{l}0.00 \pm \\
0.00\end{array}$ & $\begin{array}{l}25.00 \pm \\
0.00^{\mathrm{b}}\end{array}$ \\
\hline KLE. & $11.00 \pm 0.00$ & $\begin{array}{l}18.00 \pm \\
1.00^{\mathrm{a}}\end{array}$ & $\begin{array}{l}13.00 \pm \\
0.00\end{array}$ & $\begin{array}{l}10.00 \pm \\
1.00\end{array}$ & $\begin{array}{l}0.00 \pm \\
0.00\end{array}$ & $\begin{array}{l}28.50 \pm \\
1.50^{\mathrm{b}}\end{array}$ \\
\hline PSE. & $13.00 \pm 0.00$ & $\begin{array}{l}17.50 \pm \\
0.50^{\mathrm{a}}\end{array}$ & $\begin{array}{l}14.50 \pm \\
0.50\end{array}$ & $0.00 \pm 0.00$ & $\begin{array}{l}0.00 \pm \\
0.00\end{array}$ & $\begin{array}{l}22.50 \pm \\
0.50^{\mathrm{b}}\end{array}$ \\
\hline SAL. & $11.50 \pm 0.50$ & $\begin{array}{l}16.00 \pm \\
0.00^{\mathrm{a}}\end{array}$ & $0.00 \pm 0.00$ & $0.00 \pm 0.00$ & $\begin{array}{l}0.00 \pm \\
0.00\end{array}$ & $\begin{array}{l}26.50 \pm \\
0.50^{\mathrm{b}}\end{array}$ \\
\hline
\end{tabular}

MET. CHL/METH: Methylene chloride/Methanol extract ; E.A.: ethyl acetate extract ; MET. CHL.: methylene chloride extract; HEX: hexane extract ; RES: residual extract ; GEN: gentamicin ; B.C: B. cereus ; STA: S. aureus ; E.C.: E. coli ; KLE: K. pneumoniae ; PSE: P. aeruginosa; SAL: S. typhi]. The values in the same line with different letters are statistically different at the $5 \%$ probability threshold

\subsection{Antibacterial Activity of Extracts}

The evaluation of antimicrobial activity of extracts was done by measuring the diameter of the inhibition zone around the well. The results show that the growth of bacterial species tested was inhibited in petridishes (agar well diffusion test) by extracts of E. africana excepted hexane extract on $P$. aeruginosa and $S$. aureus and methylene chloride extract on $S$. aureus. The diameters of inhibition zones obtained ranging from 10.50 $\mathrm{mm} \pm 0.50$ to $18.00 \mathrm{~mm} \pm 1.00$ (Table 3 ). These extracts exhibited the lowest activity on $S$. aureus with inhibition diameters between $10.50 \mathrm{~mm}$ \pm 0.50 and $13.00 \mathrm{~mm} \pm 0.50$. P. aeruginosa and $K$. pneumoniae were the most sensitive species to the methylene chloride/methanol extract with inhibition diameters reaching $13.00 \mathrm{~mm} \pm 0.50$. The ethyl acetate extract showed a greater inhibiting activity $(\mathrm{p}<0.05)$ on all bacterial species tested compared to other extracts. Its inhibition diameters varied from $15.0 \mathrm{~mm} \pm 0.5$ to $18.00 \mathrm{~mm} \pm 1.00$. The residual extract from the splitting 
of the methylene chloride/methanol extract was not active on any germ. However, gentamicin was more active with inhibition diameters ranging from $22.5 \mathrm{~mm} \pm 0.5$ to $27 \mathrm{~mm} \pm 1.00$.

Table 4 Inhibition parameters of the extracts of E. africana

\begin{tabular}{|c|c|c|c|c|c|c|c|}
\hline $\begin{array}{l}\text { Strains } \\
\text { Compound }\end{array}$ & Parameters & $\begin{array}{l}\text { E. } \\
\text { coli }\end{array}$ & $\begin{array}{l}\text { K. } \\
\text { pneumoniae }\end{array}$ & $\begin{array}{l}P . \\
\text { aeruginosa }\end{array}$ & $\begin{array}{l}S . \\
\text { typhi }\end{array}$ & $\begin{array}{l}S . \\
\text { aureus }\end{array}$ & $\begin{array}{l}\text { B. } \\
\text { cereus }\end{array}$ \\
\hline $\begin{array}{l}\text { E. africana } \\
\text { (Crude }\end{array}$ & $\begin{array}{l}\text { MIC } \\
(\mathrm{mg} / \mathrm{mL})\end{array}$ & 3.13 & 3.13 & 6.25 & 6.25 & 6.25 & 6.25 \\
\hline \multirow[t]{2}{*}{ extract) } & $\begin{array}{l}\mathrm{MBC} \\
(\mathrm{mg} / \mathrm{mL})\end{array}$ & $\begin{array}{l}12.5 \\
0\end{array}$ & 12.50 & 12.50 & $\begin{array}{l}25.0 \\
0\end{array}$ & 25.00 & 50.00 \\
\hline & MBC/MIC & 4.00 & 4.00 & 2.00 & 4.00 & 4.00 & 8.00 \\
\hline $\begin{array}{l}\text { E. africana } \\
\text { (Ethyl }\end{array}$ & $\begin{array}{l}\text { MIC } \\
(\mathrm{mg} / \mathrm{mL})\end{array}$ & 1.56 & 1.56 & 1.56 & 3.13 & 3.13 & 3.13 \\
\hline \multirow[t]{2}{*}{$\begin{array}{l}\text { acetate } \\
\text { fraction) }\end{array}$} & $\begin{array}{l}\mathrm{MBC} \\
(\mathrm{mg} / \mathrm{mL})\end{array}$ & 6.25 & 3.13 & 3.13 & 6.25 & 6.25 & 50.00 \\
\hline & MBC/MIC & 4.00 & 2.00 & 2.00 & 2.00 & 2.00 & 16.00 \\
\hline \multirow{3}{*}{$\begin{array}{l}\text { E. africana } \\
\text { (Methylen } \\
\text { e chloride } \\
\text { fraction) }\end{array}$} & $\begin{array}{l}\text { MIC } \\
(\mathrm{mg} / \mathrm{mL})\end{array}$ & 3.13 & 3.13 & - & - & - & 3.13 \\
\hline & $\begin{array}{l}\mathrm{MBC} \\
(\mathrm{mg} / \mathrm{mL})\end{array}$ & $\begin{array}{l}12.5 \\
0\end{array}$ & 12.50 & - & - & - & 50.00 \\
\hline & MBC/MIC & 4.00 & 4.00 & - & - & - & 16.00 \\
\hline \multirow{3}{*}{$\begin{array}{l}\text { E. africana } \\
\text { (Hexane } \\
\text { fraction) }\end{array}$} & $\begin{array}{l}\text { MIC } \\
(\mathrm{mg} / \mathrm{mL})\end{array}$ & 1.56 & 1.56 & - & - & - & 3.13 \\
\hline & $\begin{array}{l}\mathrm{MBC} \\
(\mathrm{mg} / \mathrm{mL})\end{array}$ & $\begin{array}{l}12.5 \\
0\end{array}$ & 12.50 & - & - & - & 50.00 \\
\hline & MBC/MIC & 8.00 & 8.00 & - & - & - & 16.00 \\
\hline \multirow[t]{3}{*}{ Gentamicin } & $\begin{array}{l}\text { MIC } \\
(\mu \mathrm{g} / \mathrm{mL})\end{array}$ & 5.00 & 5.00 & 5.00 & 5.00 & 5.00 & 10.00 \\
\hline & $\begin{array}{l}\text { MBC } \\
(\mu \mathrm{g} / \mathrm{mL})\end{array}$ & $\begin{array}{l}10.0 \\
0\end{array}$ & 10.00 & 10.00 & $\begin{array}{l}10.0 \\
0\end{array}$ & 10.00 & 20.00 \\
\hline & MBC/MIC & 2.00 & 2.00 & 2.00 & 2.00 & 2.00 & 2.00 \\
\hline
\end{tabular}

E. coli: Escherichia coli; K. pneumoniaea: Klebsiella pneumoniaea; P. aeruginosa: Pseudomona aeruginosa; S. typhi: Salmonella typhi; S. aureus: Staphylococcus aureus; B. cereus : Bacillus cereus

The data summarized in Table 4 below shows that, the methylene chloride/methanol, hexane, methylene chloride and ethyl acetate extracts of E. africana have antibacterial activity on at least three of six tested bacteria with MICs ranging from 1.56 to $6.25 \mathrm{mg} / \mathrm{mL}$. The most active extracts were those obtained by methylene chloride/methanol and ethyl acetate. They were active on all six bacterial species used at concentrations tested. The lowest MIC value $(1.56 \mathrm{mg} / \mathrm{mL})$ was obtained with ethyl acetate and hexane extracts against $E$. coli and $K$. pneumoniae. Methylene chloride and hexane extracts have MICs greater than $50 \mathrm{mg} / \mathrm{mL}$ on $P$. aeruginosa, $S$. aureus and S. typhi. With MBC/MIC ratios less than or equal to 4 , the methylene chloride/methanol and ethyl acetate extracts showed bactericidal activities on E. coli, K. pneumoniae, P. aeruginosa, S. typhi and $S$. aureus. All the extracts have a bacteriostatic effect on $B$. cereus (MBC/MIC > 4). This antibacterial activity exerted by the extracts of $E$. africana remains lower than that of gentamicin, which has a bactericidal activity against all germs tested with MICs of about $5 \mu \mathrm{g} / \mathrm{mL}$.

The growth inhibition of $E$. coli, $S$. aureus, S. typhi, B. cereus, $K$. pneumoniae and $P$. aeruginosa on plate agar and the minimum inhibitory and bactericidal concentration of extracts obtained show antibacterial properties of E. africana extracts. This antibacterial activity can be explained by the presence in the extracts of various groups of secondary metabolites potentially active. In fact, the phytochemical screening revealed that methylene chloride/methanol extract contains phenolic compounds as flavonoids and tannins. Kil et al. [29], Al-Habib et al. [30], Kumar et al. [31] and Souza et al. [32] reported that the antimicrobial activities of some plant extracts are due to high grade of phenolic compounds. Cushinie and Lamb [33] suggested that flavonoids are able to damage cytoplasmic membrane (perforation and/or reduction of membrane fluidity), inhibit synthesis of nucleic acids (caused by inhibition of topoisomerase) and inhibit energetic metabolism (caused by inhibition of NADH-cytochrome $\mathrm{C}$ reductase). The antimicrobial action of tannins may be related to the fact that these compounds are able to complex macromolecules such as polysaccharides and proteins. Tannins may cause denaturation and consequently change the proteins of the bacterial cell membrane. This action occurs with proteins due to non-specific interactions, such as hydrogen bridges, hydrophobic effects, and through covalent bonds [34] in Pandini et al. [35].

Many studies have demonstrated antimicrobial activity of plants commonly used by traditional medicine [36-41]. Fabry et al. [42] suggested that the crude extract was active in the case of MIC $<8 \mathrm{mg} / \mathrm{mL}$. Furthermore, in a study carried out by Pandini et al. [35], it was considered that if the extracts displayed an MIC less than $12.5 \mathrm{mg} / \mathrm{mL}$, the antimicrobial activity was high, from 12.5 to $25 \mathrm{mg} / \mathrm{mL}$, the antimicrobial activity was moderate, from 50 to $100 \mathrm{mg} / \mathrm{mL}$, the antimicrobial activity was weak and over $100 \mathrm{mg} / \mathrm{mL}$, the extract was considered inactive. In this study, the MICs obtained were less than $12.5 \mathrm{mg} / \mathrm{mL}$ and considered promising. The antibacterial activity of these extracts herein reported corroborates those of Silva et al. [43] with MIC of $1.56 \mathrm{mg} / \mathrm{mL}$ on S. aureus and those of Fabry et al. [42] with MIC50 of $8 \mathrm{mg} / \mathrm{mL}$ on the tested bacteria. However, these results aren't consistent with those obtained by Teke et al. [36] and Tchana et al. [38]. The differences observed between these results could be justified by the fact that these plants were harvested in different regions. Indeed, the study carried out by Inacio et al. [44] have shown that antimicrobial activity of medicinal plants would be influenced by some factors as climate, seasons of the year, phenological stage, temperature, altitude, humidity, soil constituents, plant age. These factors can significantly affect the quality and or quantity of bioactive compound in medicinal plants $[45,46]$.

According to the synergism between the bioactive compounds that are extracted by the solvent or to the method of extraction employed, the raw extracts of plant can many times present a lower antimicrobial activity against pathogens $[47,48]$. So, the use of solvent with different polarities in the achievement of the extracts promoted a differentiated antibacterial activity in this study. This reflects an increase in the antibacterial activity of this plant through splitting. The ethyl acetate extract gave the best activities. The ethyl acetate is a solvent of medium polarity, a trait that enables the extraction of some chemical classes of secondary metabolites [49]. The bactericidal and bacteriostatic activities of these extracts further justified the use of E. africana stem bark in traditional medicine for the treatment of gastrointestinal infections.

\subsection{Anti-Ulcerogenic Activity}

The results presented in Table 5 below show that the methylene chloride/methanol extract of $E$. africana inhibits the formation of indomethacin-induced gastric lesions in rats. This inhibition was accompanied by an increase in mucus mass from $57.95 \pm 4.10 \mathrm{mg}$ in negative control animals to $94.67 \pm 5.35$ and $102.21 \pm 8.81 \mathrm{mg}$ in animals treated with 200 and $400 \mathrm{mg} / \mathrm{kg}$, respectively. This anti-ulcerogenic activity of the methylene chloride/methanol extract of E. africana resulted in a reduction in ulceration surfaces from $10.90 \pm 0.33 \mathrm{~mm}^{2}$ in negative control animals to $4.25 \pm 0.22$ and $3.50 \pm 0.18 \mathrm{~mm}^{2}$ when the extract was administered at doses of 200 and $400 \mathrm{mg} / \mathrm{kg}$, respectively. In addition, the ulceration index, with a value of $2.84 \pm 0.12$ in negative control animals, increased to $1.98 \pm 0.24$ (an inhibition percentage of $30.28 \%$ ) and $1.36 \pm$ 0.14 (an inhibition percentage of $52.11 \%$ ) when the crude extract was administered in animals at $200 \mathrm{mg} / \mathrm{kg}$ and $400 \mathrm{mg} / \mathrm{kg}$, respectively. Sucralfate, the reference anti-ulcer agent used at $60 \mathrm{mg} / \mathrm{kg}$, significantly $(p<0.01)$ inhibited the ulcerogenic effect of indomethacin on the gastric mucosa. This inhibition resulted in a decreased surface area with ulceration index to $0.90 \pm 0.14 \mathrm{~mm}^{2}$ and $1.12 \pm 0.31$, respectively, representing an inhibition percentage of $60.56 \%$. The results obtained justify the cytoprotective properties of the stem bark of E. africana. These results showed that the methylene chloride/methanol extract of $E$. africana at 200 and $400 \mathrm{mg} / \mathrm{kg}$ significantly $(\mathrm{p}<0.5)$ protects the gastric mucosa against indomethacin-induced damage. This cytoprotection was accompanied by significant mucus production $(\mathrm{p}<0.05)$ in test animals. This meant that the methylene chloride/methanol extract of $E$. africana act by stimulating prostaglandin synthesis. Indeed, natural compounds can exert a cytoprotective effect by inducing the expression of cyclooxygenases in the gastric mucosa [50]. Cyclooxygenases catalyse the synthesis of prostaglandins from arachidonic acid. Prostaglandins are substances that promote mucus secretion and play an important role in maintaining the integrity of the stomach lining against irritants [51]. Mucus in combination with bicarbonate forms a thick protective layer of the gastric mucosa against corrosive agents. Another mode of action would be direct mucosal stimulation by the extract similar to that of prostaglandins, and not related to endogenous prostaglandins. Tan et al. in 2000 [52] showed that plant extracts could produce their antiulcerogenic activity through mechanisms similar to those of prostaglandins. This cytoprotective activity could be attributed to the phenolic compounds present in the crude extract of E. africana. In addition, flavonoids have been shown to increase the number of neutral glycoproteins, mucus secretion and bicarbonate ions [53], increase the content of endogenous prostaglandins in the mucosa and inhibit acid secretion [54]. Tannins precipitate microproteins at the site of peptic ulcer, forming a promote resistance to the action of proteolytic enzymes, an associated activity against Helicobacter pylori [55]. However, inhibition of prostaglandin synthesis does not appear to be the exclusive mechanism for induction of gastric lesions by non-steroidal anti-inflammatory drugs. Other mechanisms such as induction of oxidative damage through 
increased lipid peroxidation and inactivation of peroxidases in the gastric mucosa are also involved [56]

Table 5 Effects of Methylene chloride/Methanol extract on indomethacin-induced gastric ulcer

\begin{tabular}{|c|c|c|c|c|c|c|}
\hline Treatment & $\begin{array}{l}\text { Dose } \\
(\mathrm{mg} / \mathrm{kg})\end{array}$ & $\begin{array}{l}\text { Avg. } \\
\text { mucus } \\
\text { mass (mg) }\end{array}$ & $\begin{array}{l}\text { Ulceration } \\
\text { surface } \\
\left(\mathrm{mm}^{2}\right)\end{array}$ & $\begin{array}{l}\text { Ulcerated } \\
\text { surface } \\
\%\end{array}$ & $\begin{array}{l}\text { dUlceration } \\
\text { index }\end{array}$ & $\begin{array}{l}\text { Inhibition } \\
\text { (\%) }\end{array}$ \\
\hline DMSO 10\% & - & $\begin{array}{l}57.95 \pm \\
4.10^{\mathrm{a}}\end{array}$ & $\begin{array}{l}10.90 \pm \\
0.33^{\mathrm{a}}\end{array}$ & 1.61 & $\begin{array}{l}2.84 \pm \\
0.12^{\mathrm{a}}\end{array}$ & - \\
\hline $\begin{array}{l}\text { MET } \\
\text { CHL/METH }\end{array}$ & 200 & $\begin{array}{l}94.67 \pm \\
5.35^{b}\end{array}$ & $\begin{array}{l}4.25 \\
\pm 0.22 \mathrm{c}\end{array}$ & 0.63 & $\begin{array}{l}1.98 \pm \\
0.24 b\end{array}$ & 30.28 \\
\hline extract & 400 & $\begin{array}{l}102.21 \pm \\
8.81^{c}\end{array}$ & $\begin{array}{l}3.50 \pm \\
0.18^{c}\end{array}$ & 0.52 & $\begin{array}{l}1.36 \pm \\
0.14 \mathrm{c}\end{array}$ & 52.11 \\
\hline Sucralfate & 60 & $\begin{array}{l}75.17 \pm \\
4.13^{\mathrm{a}}\end{array}$ & $\begin{array}{l}0.9 \pm 0.14 \\
d\end{array}$ & 0.13 & $\begin{array}{l}1.12 \pm \\
0.31^{c}\end{array}$ & 60.56 \\
\hline
\end{tabular}

The values in the same column with different letters are statistically different at the $5 \%$ probability threshold.

\subsection{Antioxidant Activity (Reduced Glutathione and Malondialdehyde Levels)}

The evaluation of antioxidant activity of methylene chloride/methanol extract was done by determination of reduced glutathione and malondialdehyde levels in stomach homogenates. Indomethacin administered at a dose of $50 \mathrm{mg} / \mathrm{kg}$ body weight resulted in a decrease in reduced glutathione level in the stomach tissue. The latter decreased from $0.28 \pm 0.03 \mathrm{mmol} / \mathrm{g}$ of tissue in normal animals to $0.16 \pm 0.02 \mathrm{mmol} / \mathrm{g}$ of tissue in negative control animals. Pre-treatments with methylene chloride/methanol extract at doses of 200 and $400 \mathrm{mg} / \mathrm{kg}$ body weight increased the concentration of reduced glutathione $(0.22 \pm 0.05$ and 0.32 $\pm 0.15 \mathrm{mmol} / \mathrm{g}$ organ, respectively). Indomethacin increased the MDA level in the stomach tissue. It increased from $4.60 \pm 1.21 \mathrm{nmol} / \mathrm{g}$ of tissue in normal animals to $8.68 \pm 1.68 \mathrm{nmol} / \mathrm{g}$ of tissue in negative control animals. This MDA level was reduced by pre-treatment with methylene chloride/methanol extract. Compared to the negative control, this reduction was significant $(\mathrm{p}<0.05)$ at $400 \mathrm{mg} / \mathrm{kg}(3.54 \pm 0.93 \mathrm{nmol} / \mathrm{g})$.

Exposure of membrane lipids to oxygen-derived free radicals stimulates their peroxidation. MDA, a by-product of this lipid peroxidation, indicates the presence of oxidative stress in tissues [57]. Thus, the decrease in reduced glutathione level associated with the increase in MDA level in the homogenates of stomach tissue in negative control animals reflects the oxidative effect of indomethacin on the stomach of rats. However, the increased reduced glutathione level and decreased MDA level observed in pretreated animals have shown that E. africana bark prevents oxidative stress induced by indomethacin in the stomach tissue. This increase in reduced glutathione level would show that the reactive oxygen species produced in the stomach tissue have been managed by antioxidant enzymes other than glutathione peroxidase. Catalase is an enzyme that is extremely active in the management of reactive oxygen species. It is most active when the oxidative stress level is high or the amount of glutathione peroxidase is limited. In addition, the methylene chloride/methanol extract of E. africana could exercise its antioxidant activity by directly trapping free radicals. Njayou et al. [28] showed that this plant has strong antioxidant properties. This activity would be attributed to the polyphenols present in this extract. Indeed, phenolic compounds are antioxidants in vitro and are capable of producing in vivo antioxidant protection against biomolecular damage and peroxidation of cell membranes $[58,59]$.

In addition, Zayachkivska et al. [53] have demonstrated that polyphenolic substances have anti-inflammatory activity on the gastrointestinal tract; they activate tissue repair through the expression of several growth factors, antioxidant activity and the trapping of reactive oxygen species.

\section{Conclusion}

Natural substances are becoming increasingly important in therapy. Indeed, medicinal plants are real chemical factories from which maximum benefit should be derived. This study focused on the evaluation of the antibacterial and anti-ulcerogenic activities of the bark of Entada africana. The results obtained showed that the trunk bark of E. africana contains polyphenols. This bark has antibacterial activity in vitro, protect rat stomachs from indomethacin-induced damage and prevent oxidative stress in stomach tissue. These antibacterial and anti-ulcerogenic properties of E. africana bark highlighted in this work would explain the use of this plant in traditional medicine for the treatment of gastrointestinal disorders.

\section{References}

[1] Medical Research Council, Diarrheal Pathogens Research Unit, 2012. http://www.mrc.ac.za/diarrhoeal/diarrhoeal.htm (Accessed on 19.03.2017).

[2] B.C. Forsberg, M.G. Petzold, G. Tomson, P. Allebeck, Diarrhoea case management in low and middle-income countries an unfinished agenda, Bull. WHO 85 (2007) 42-48.

[3] P. Luc, Infectious gastroenteritis, (2003). http://www.fmed.ulaval.ca/med18654/prive/Cours\%2018/Pdf/GE.pdf (Accessed on 20.04.2018).

[4] N. Joëlle, Pediatrics and humanitarian health, DU sanitary and humanitarian CHU Montpellier, 2012.

[5] J. Sarles, M. Drancourt, J.P. Bernard, Acute diarrhea in children and adults, DCEM 2 course - module no. 12, Hepato-Gastro-Enterology, Faculty of Medicine of Marseille, France, 2006.

[6] W. Ganong, Medical Physiology, 19th Edn., Masson, Quebec, 2001.

[7] Sherwood, Human Physiology, 2nd Edn., De Boeck, Paris, 2006.

[8] S. Lillian, S. Smelter, B. Bare, Functions digestives, De Boeck, Paris, 2006

[9] K. Aziz, D. Bonnet, Hepato-gastroenterology, Masson, Paris, 2008.

[10] F. Ankouane, G. Ngatcha, M. Kowo, A.W. Ndam, M. Tagne Sartre, et al., Demography analysis and endoscopy analysis of patients with peptic ulcer at Yaounde in Cameroon: what has changed since the 1990s?, Med. Black Africa 6307 (2016) 409-415.

[11] WHO, Report of Cameroon health profile, http://www.who.int/countries/cmr/fr/ (Accessed on 20.08.2017)

[12] H.M. Burkill, The useful plants of west tropical Africa, Royal Botanic Gardens Kew 3 (1995) 450-483.

[13] D. Diallo, S.P. Berit, H.A. Torun, Liljebäck, E. Terje, Michaelsen, Polysaccharides from the roots of E. africana Guill et Perr., Mimosaceae, with complement fixing activity, J. Ethnopharmacol. 74 (2001) 159-171.

[14] P.F. Moundipa, F. Njayou, S. Yanditoum, B. Sonké, F. Tchouanguep, Medicinal plants used in the Bamun region of the Western Province of Cameroon against jaundice and other liver disorders, Camer. J. Biochem. Sci. 12 (2002) 39-46.

[15] A. Tibiri, W.S. Richard, O. Noufou, Evaluation of antioxidant activity, total phenolic and flavonoid contents of Entada africana Guill. et Perr. (Mimosaceae) organ extracts, Res. J. Med. Sci. 4 (2010) 81-87.

[16] I. Obidike, M. Emeje, Microencapsulation enhances the anti-ulcerogenic properties of Entada Africana leaf extract, J. Ethnopharmacol. 137 (2011) 553 561.

[17] P. Prakash, N. Gupta, Therapeutic uses of Ocimum sanctum (Tulsi) with a note on eugenol and its pharmacological actions: A Short Review, Ind. J. Physiol. Pharmcol. 49(2) (2005) 125-131.

[18] O.O. Odebiyi, E.A. Sofowora, Phytochemical screening, Nigeria medicinal plant II, Loydia 41 (1978) 234-246.

[19] J.B. Harbone, Phytochemical methods, Chapman and Hall, Ltd, London, 1973.

[20] A.A. Adesokan, M.A. Akanji, M.T. Yakubu, Antibacterial potentials of aqueous extract of Enantia chlorantha stem bark, Afr. J. Biotechnol. 6(22) (2007) 25022505.

[21] CLSI, Methods for dilution antimicrobial susceptibility tests for bacteria that grow aerobically; approved standard, $9^{\text {th }}$ Ed., CLSI document M07-A9. Clinical and Laboratory Standards Institute, 950 West Valley Road, Suite 2500, Wayne, Pennsylvania 19087, USA 2012.

[22] J.L. Avril, J.L. Fauchère, General and medical bacteriology, Ellipses Publish, Paris, 2002.

[23] G. Santhakumari, N.R. Pillai, Effects of Nimbidin on acute and chronic gastroduodenal ulcer models in experimental animals, Planta Med. 50 (1984) 143146.

[24] M.J. Martin, F. Marhhuenda, C. Perez-Guerrero, J.M. Franco, Antiulcer effect of naringin on gastric lesions induced by ethanol in rats, Pharmacol. 9 (1993) 144-150.

[25] P.V. Tan, G.N. Nditafon, M.P. Yewah, J.F. Ayafor, T. Dimo, Eremomastax peciosa: effect on the leaf aqueous extract on ulcer gastric secretion in rats, J. Ethnopharmacol. 54 (1996) 139-142.

[26] G.L. Ellman, Tissue sulfhydryl group, Arch. Biochem. Biophys. 82 (1959) 70-77.

[27] K.M. Wilbur, F. Bernheim, O.W. Shapiro, Determination of lipid peroxidation, Arch. Biochem. Biophys. 24 (1949) 305-310.

[28] F.N. Njayou, E.C. Aboudi, M.K. Tandjang, A.K. Tchana, B.T. Ngadjui, P.F. Moundipa, Hepatoprotective and antioxidant activities of sterm bark extract of Khaya grandifoliola (welw) CDC and Entada africana Guill. et Perr, J. Nat. Prod. 6 (2013) 73-80.

[29] H.Y. Kil, E.S. Seong, B.K. Ghimire, I.M. Chung, S.S. Kwon, et al., Antioxidant and antimicrobial activities of crude sorghum extract, Food Chem. 115 (2009) 1234-1239.

[30] A. AL-Habib, E. AL-Saleh, A. Safer, M. Afzal, Bactericidal effects of grape seed extracts on methicillin resistant Staphylococcus aureus (MRSA), J. Toxicol. Sci. 35 (2010) 357-364.

[31] K.A. Kumar, M. Narayani, A. Subanthini, M. Jayakumar, Antimicrobial activity and phytochemical analysis of citrus fruit peels - utilization of fruit waste, Int. J. Eng. Sci. Tech. 3 (2011) 5414-5421.

[32] J.G. Souza, A.G. Toledo, C.B. Santana, C.V. Santos, A.P. Mallmann, et al., Chemical composition and antibacterial activity of essential oil and leaf extracts of Zanthoxylum caribaeum Lam. against serotypes of Salmonella, Rev. Bras. Saude Prod. Anim. Salvador 18 (2017) 446-453.

[33] T.P. Cushnie, A.J. Lamb, Recent advances in understanding the antibacterial properties of flavonoids, Int. J. Antimicrob. Agents 38 (2011) 99-107.

[34] C.M.O. Simões, E.P. Schenkel, G. Gosman, Pharmacognosy from plant to medicine, Porto Alegre, UFSC and UFRGS, Brazil, 2007.

[35] J.A. Pandini, F.G.S. Pinto, M.C. Scur, L.F.A. Alves, C.M. Castilho, Antimicrobial, insecticidal, and antioxidant activity of essential oil and extracts of Guarea kunthiana A. Juss, J. Med. Plant Res. 9 (2015) 48-55. 
[36] G.N. Teke, P.K. Lunga, H.K. Wabo, J.R. Kuiate, G. Vilarem, et al., Antimicrobial and antioxidant properties of methanol extract, fractions and compounds from the stem bark of Entada abyssinica Stend ex A. Satabie, BMC Complement. Altern. Med. 11(1) (2011) 1-8.

[37] E.M. Tekwu, A.C. Pieme, V.P. Beng, Investigations of antimicrobial activity of some Cameroonian medicinal plant extracts against bacteria and yeast with gastrointestinal relevance, J. Ethnopharmacol. 142 (2012) 265-273.

[38] M.E.S. Tchana, A.G. Fankam, A.T. Mbaveng, E.T. Nkwengoua, J.A. Seukep, et al., Activities of selected medicinal plants against multi-drug resistant Gramnegative bacteria in Cameroon, Afr. Health Sci. 14 (2014) 167-172.

[39] I.L. Elisha, F.S. Botha, McGawl, J.N. Eloff, The antibacterial activity of extracts of nine plant species with good activity against Escherichia coli against five other bacteria and cytotoxicity of extracts, BMC Complement. Altern. Med. 17 (2017) $1-10$.

[40] F.V. De Assis, F.L. Siqueira, I.E. Gonçalves, R.P. Lacerda, R.A. Nascimento, et al., Antibacterial activity of Lamiaceae plant extracts in clinical isolates of multidrug-resistant bacteria, Annal. Braz. Acad. Sci. 90 (2018) 1665-1670.

[41] [41] M.R. Jangra, S. Jangra, R. Kumar, and K.S. Nehra, Antimicrobial activity of some Indian medicinal plants against the soil bacteria, Int. J. Pure App. Biosci. 6 (2018) 461-466.

[42] W. Fabry, O. Paul, A. Rainer, Antibacterial activity of East African medicinal, J. Ethnopharmacol. 60 (1998) 79-84.

[43] O. Silva, A. Duarte, J. Cabrita, M. Pimentel, A. Diniz, E. Gomes, Antimicrobial, activity of Guinea-Bissau traditional remedies, J. Ethnopharmacol. 50 (1996) 55-59.

[44] M. C. Inacio, T.A. Paz, B.W. Bertoni, A.M.S. Pereira, Effect of environmental and phenological factors on the antimicrobial activity of Cochlospermum regium (Schrank) Plig roots, Maringa 38 (2016) 467-473.

[45] D.P. Pavarini, S.P. Pavarini, M. Niehues, N.P. Lopez, Exogenous influences on plant secondary metabolite levels, Animal Feed Sci. Technol. 176 (2012) 5-16.

[46] A. Szakiel, C. Paczkowski, M. Henry, Influence of environmental abiotic factors on the content of saponins in plants, Phytochem. Rev. 10 (2011) 471-491.
[47] D. Lee, C.Y. Yu, Antioxidant and antimicrobial activities of crude sorghum extract, Food Chem. 115 (2009) 1234-1239.

[48] J. Delgado-Adámez, M.F. Fernandez-Leon, B. Velardo-Micharet, D. GonzalezGomez, In vitro assays of the antibacterial and antioxidant activity of aqueous leaf extracts from different Prunus salicina Lindl. cultivars, Food Chem. Toxicol. 50 (2012) 2481-2486.

[49] V. Cechinel-Filho, R.A. Yunes, Strategies for obtaining pharmacologically active compounds from medicinal plants: concepts on structural modification to optimize activity, Química Nova 21 (1998) 99-105.

[50] R.A. Orlando, A.M. Gonzales, L.A. Hunsaker, C. Franco, R.E. Roger, et al., Inhibition of nuclear factor JB activation and cyclooxygenase-2 expression by aqueous extracts of Hispanic medicinal herbs, J. Med. Food 13 (2010) 888-895.

[51] J.M. Antonio, J.S. Gracioso, W. Toma, L.C. Lopez, F. Oliveira, A.R.M. Souza Brito, Antiulcerogenic activity of ethanol extract of Solanum variable (false jurubeta), J. Ethnopharmacol. 93 (2004) 83-88.

[52] P.V. Tan, B. Nyasse, Anti-ulcer compound from Voacanga africana with possible histamine $\mathrm{H}_{2}$ receptor blocking activity, Phytomed. 7 (2000) 509-515.

[53] O.S. Zayachkivska, S.J. Konturek, D. Drozdowicz, P.C. Konturek, T. Brzozowski, M.R. Ghegotsky, Gastroprotective effects of flavonoïds in plant extracts, J. Physiol. Pharmacol. 56 (2005) 219-231.

[54] F. Borrelli, A.A. Izzo, The plant kingdom as a source of anti-ulcer remedies, Phytotherapy Res. 8 (2000) 581-591.

[55] N.Z. De Jesus, H. De Souza Falcão, I.F. Gomes, T.J. De Almeida Leite, G.R. De Morais Lima, Tannins, peptic ulcers and related mechanism, Int. J. Mol. Sci. 13 (2012) 3203-3228.

[56] Y. Pérez, A. Oyarzabal, R. Mas, V. Molina, S. Jiménez, Protective effect of D-002, a mixture of beeswax alcohols against indomethacin-induced gastric ulcers and mechanism of action, J. Nat. Med. 67 (2013) 182-189.

[57] A. Favier, Oxidative stress, Chem. News (2003) 108-115.

[58] H. De Groot, Reactive oxygen species in tissue injury, Hepato-Gastroenterology, 41 (1994) 328-332.

[59] P.A. Grace, Ischaemia-reperfusion injury, Brit. J. Surgery 81 (1994) 637-647. 